\title{
Production of bio-insecticide from extracted carica papaya using NADES solvent with ultrasound-assisted extraction (UAE)
}

\author{
Tibrizi Ahmad ${ }^{1}$, Zikri M. Fauzy ${ }^{1}$, Yoshia ${ }^{1}$, T S Utami ${ }^{1, *}$, R Arbianti ${ }^{1}$, and H Hermansyah ${ }^{1}$ \\ ${ }^{1}$ Department of Chemical Engineering, University of Indonesia, Depok 16424, Indonesia
}

\begin{abstract}
Bioinsecticide is a kind of organic pesticides that are easily degraded in nature and their residues are relatively unobstrusive to the plants and surrounding environment. The raw material of bioinsecticide production can be derived from the abundant plant wastes and has a cysteine protease compound that can damage the tissue and digestive system in plant pests, namely papaya waste. The content of cysteine protease in papaya waste in mostly in papaya skin that can be extracted using Ultrasound-assisted extraction (UAE) by varying sonication time and solid-to-liquid ratio with NADES solvent. Those variations will be comparaed using the enzyme activity test and the evication test. The results indicated that NADES solvent proved to be efficient solvents for extraction of papaya because papaya contains alkaloid that can be extracted by NADES with ChCl-oxalid acid is the type of NADES solvent.
\end{abstract}

\section{Introduction}

Indonesia as an agricultural country has considerable agricultural potential to contribute to national development and economy. Based on data obtained from the Indonesian Central Statistic (BPS) in 2009, the number of farmers reached $44 \%$ of the total workforce in Indonesia or about 46.7 million people. The figures are one indicator that agricultural potential is still high enough for the advancement of the agricultural sector in national development in the population for the Indonesia population. The extent of agricultural land undertaken by Indonesia is one of the factors that support for the population to make the agricultural sector as a "Family Income" which is about 8 million $\mathrm{Ha}$ (Center for Agricultural Information System Data, 2014).

However, along with the increasing quantity of agriculture in Indonesia, should be followed by improving the quality of agriculture itself. Generally, one of the indicators or parameters commonly used to be demonstrate agricultural quality is the number of pests that damage crops in certain areas (Henki, 2013). Generally, famers use pesticides as a material to control pest organisms in plants.

Pesticides are things to kill plant pests whose use is relatively easy and has a fast working power and can be applied in every place and time on a large area in a short time (Soemirat, 2003). According to the Indonesian Ministry of health in 1998, the percentage of pesticide use is a follows : insecticide, $(55.42 \%)$, herbicide $(12.25 \%)$, fungicide $(12.05 \%)$, rapelen $(3.61 \%)$, wood preservative $(3.61 \%)$, growth regulators $(3.21 \%)$, rodenticides $(0.4 \%)$ and others.

In the other hand, the use of pesticides provides benefits to agricultural productivity, but the other hand, pesticides have a negative impact on public health and the environment. Approximately, $40 \%$ of deaths in the world are caused by environmental pollution including the crops consumed by humans (Sulistyoningrum, 2008). While $80 \%$ of thousands of pesticides and other chemicals used today say almost $10 \%$ are carcinogenic or can cause cancer . A study of cancer has also stated that abouth 1.4 million cancers in the world caused by pesticides.

Organic pesticides or commonly known as bioinsecticides are pesticides derived from plants to control the population of plant pests or other plant pest organisms (OPT). This organic pesticide is easy to decompose in nature and safe for human health so that its use suitable to replace the type of chemical pesticides commonly used by farmers. One source of bioinsecticide that began to be used in recent time is papaya waste that abundant availability in Indonesia and the content of alkaloids compounds In the waste that can inhibit the growth of plant pests.

In addition to the change of pesticide type, the selected extraction method should also consider the environmental aspects especially in the solvent decomposition process after the extraction process is over. The Soxhlet, maceration, and supercritical $\mathrm{CO} 2$ extraction methods are known to produce toxic organic solvents in large quantities so that are development of other methods that are environmentally friendly and can be produce on a commercial scale (Mukhriani, 2014). Ultrasonic wave extraction is an extraction method that uses a small amount of solvent and minimal energy usage so it is suitable to replace the commonly used type of method (Yang, et al., 2011).

Corresponding author: nana@che.ui.ac.id 


\section{Method}

\subsection{Ultrasound-assisted Extraction}

Ultrasound-assisted Extraction (UAE) is a maceration method (incorporating plant powders and suitable solvents into a closed inert container) modified using ultrasound aid (high frequency signal, $20 \mathrm{kHz}$ ). Containers containing sample powders are placed in ultrasonic and ultrasound containers. This is done to provide mechanical pressure on the cell to provide mechanical pressure on the cell to produce a cavity in the sample. Cell damage can cause increased solubility of the compound in the solvent and increase the extraction rate (Mukhriani, 2014)

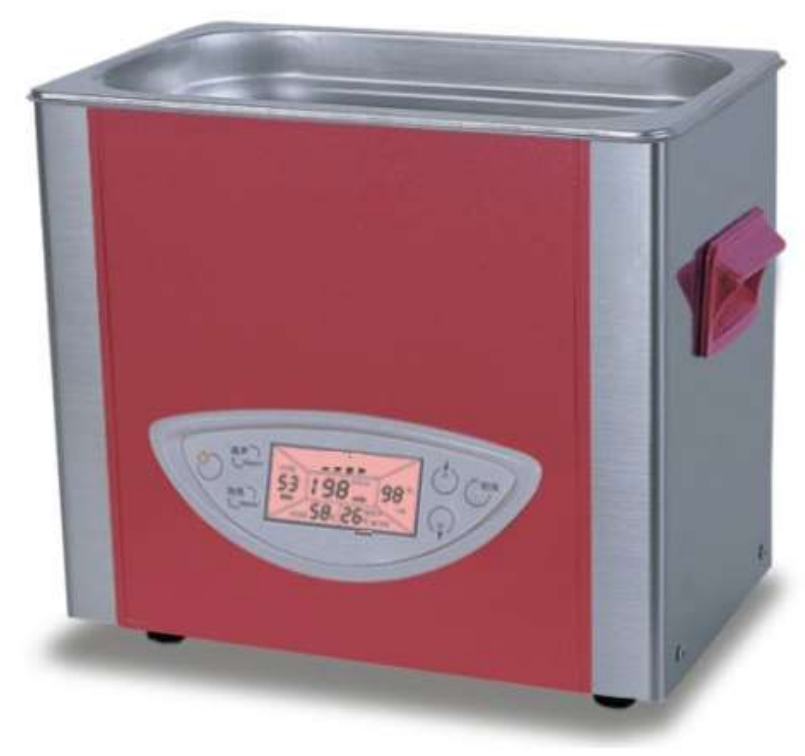

Fig. 1. Ultrasound-assisted extractor

The workings of ultrasonic methods of contracting are as follows: ultrasonic waves are formed from local ultrasonic generation from micro cavitation around the material to be extracted so that there is heating to the material, thereby releasing the extract compound. There is a double effect generated, ie the cell wall clutter so as to liberate the content of the compounds present therein and local heating in the liquid and increase the diffusion of the extract. Kinetic energy is passed to all parts of the liquid, followed by the emergence of cavitation bubbles on the walls or surfaces thereby increasing the mass transfer between the solid-liquid surfaces. The resulting mechanical effects are increased penetration of the fluid to the cell membrane wall, supporting the release of cell components, and increasing mass transfer (Keil, 2009). Ultrasonic cavitation produces a breaking force that will break the cell wall mechanically and increase the transfer of material (Liu, 2503-2511).

\subsection{Active compunds in papaya waste}

Based on research conducted by Konno (Julaily \& Setyawati, 2013), that papaya sap contains groups of cysteine protease enzymes such as papain and kimopapain. The papaya sap also produces alkaloid group compounds, terpenoids, flavonoids, and nonprotein amino acids that are highly toxic to plant-eating insects. The presence of chemical compounds in papaya plants contained can kill off the organisms. Saponins and alkaloids are stomach poisoning or stomach poison. When the compound enters the body of the insect, its digestive apparatus will become disturbed (Firda, 2017). Alkaloids are also able to inhibit the growth of insects, especially three major hormones in insects, namely the hormone brain (brain hormone), edonone hormone, and growth hormone (juvenile hormone). The lack of such hormones can lead to metamorphosis failure. Flavonoids are chemical compounds in papaya leaves that can work as a strong inhibitor of respiration or as a respiratory toxin. Flavonoids have a work that is by entering into the body of the caterpillar through the respiratory system which will lead to decreased nerve function and damage to the respiratory system and resulted in the caterpillar can not breathe and eventually die (Firda, 2017). Flavonoids can also inhibit the feeding power of insects (anti-feedant). When these compounds enter the insect body, then the digestive tool will be disrupted. This compound also works by inhibiting the taste receptors in the insect's mouth area. This resulted in the insect failing to get a taste stimulus so unable to recognize the food. As a result the insects died of hunger.

\subsection{Procedure}

The first stage is physical extraction with blending method where it aims to prevent browsing process on enzyme during extraction process and avoid pollutant substances other than protein will not settle in the enzyme. The papaya plant part was blended for 20 minutes using sodium chloride $(\mathrm{NaCl})$ and sodium bisulfite (NaHSO3) solvent which then added $1 \mathrm{M}$ phosphate buffer solution under 100C operating conditions for 24 hours and then filtered with nylon filter.

The next step is testing the protein concentration by using the lowry method. The extract results obtained are still in the form of crude so that it will be given folin and biuret reagents for later measured absorbance to be plotted into the standard curve for known concentration of enzymes contained in the extract.

The next test is to determine the enzyme activity by calculating the concentration of thyroxine formed based on the measured absorbance value of the sample which has been given folin reagent. The thyroxine is chosen as standard laurtan because thyroxine is the enzymatic reaction product of papain with Casein substrate.

The last test is a measurement of the effectiveness of bioinsecticides made, that is by testing the efficacy. This test is done by giving bioinsektisida on corn crop which is then given to the grayak worm which is tested. The data taken in the percentage of the caterpillar is dead and the percentage of leaves are inedible. 


\section{Result and Discussion}

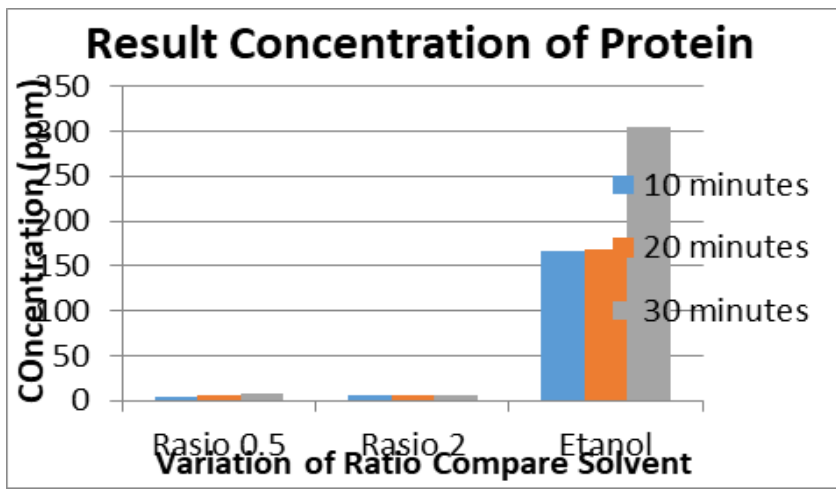

Fig. 2. Concentration of Protein

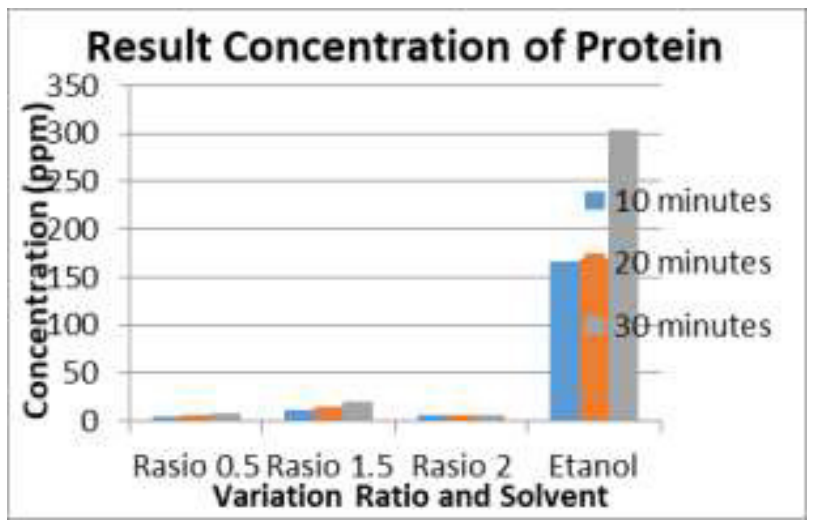

Fig. 3. Variation of Concentration and Ethanol

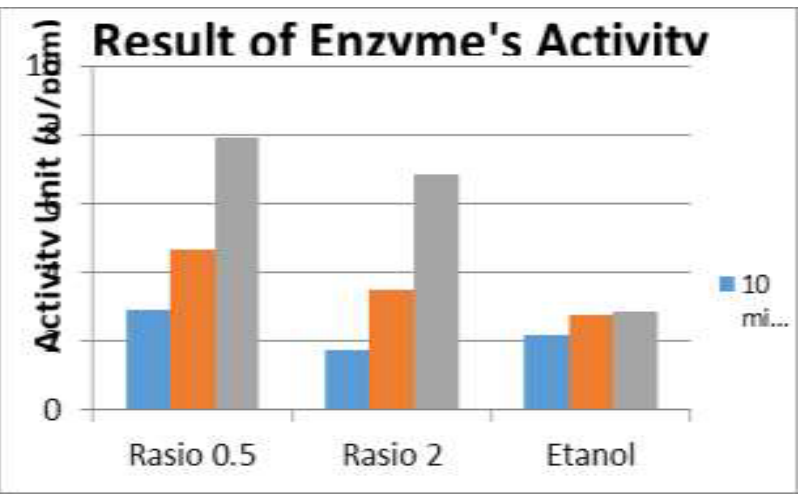

Fig. 4. Graphic of Activity Enzyme and Solvent Ratio

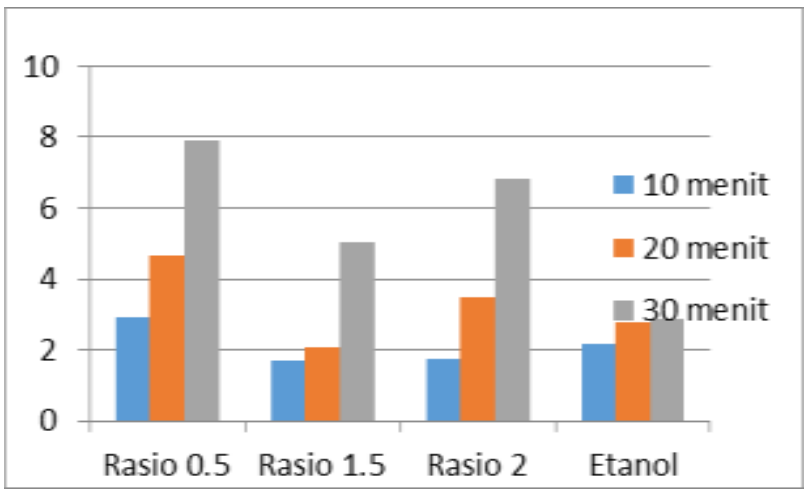

Fig. 5. Differences between Each Ratio of Solvent and Ethanol

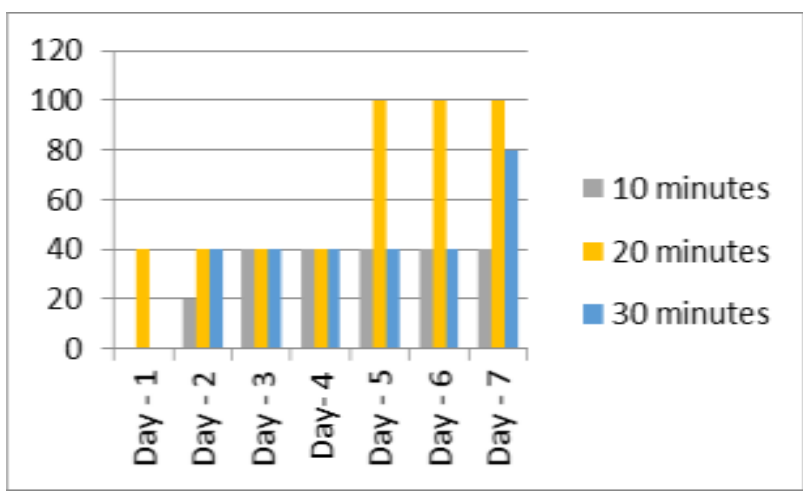

Fig. 6. Result of Efication Test for Ratio Mol 0.5

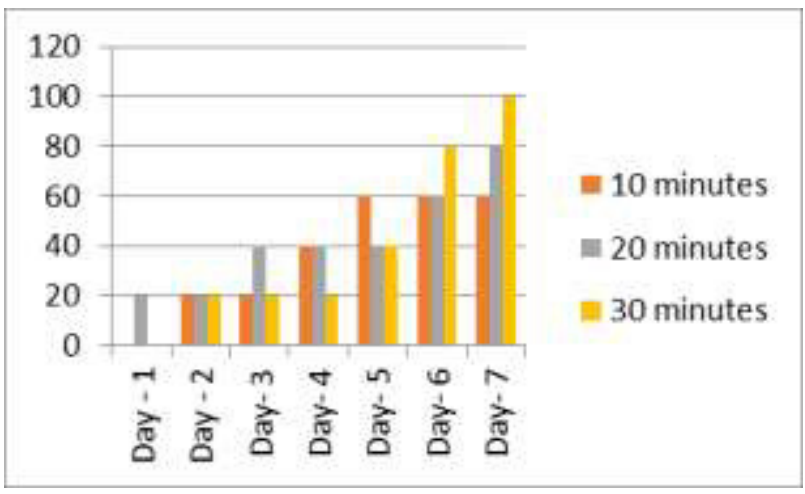

Fig. 7. Result of Efication Test for Ratio Mol 1.5

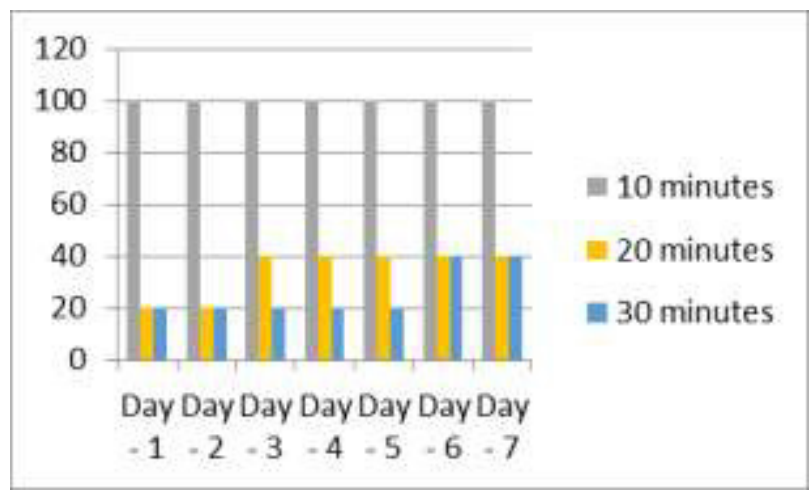

Fig. 8. Result of Efication Test for Ratio Mol 2

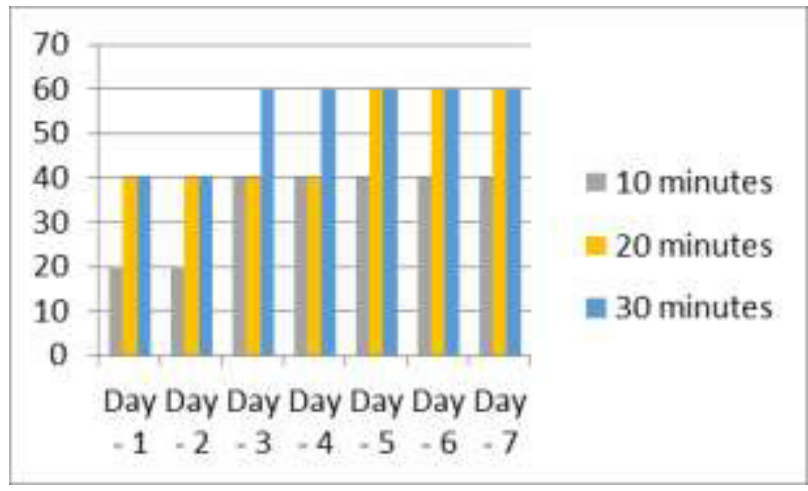

Fig. 9. Result of Efication Test for Ethanol

The above graph is the result of an experiment conducted to test the effectiveness of NADES solvent against ethanol which is a conventional solvent. There is a wide variety of mole ratios between HBD and HBA 
which are NADES compound compounds. Variations ranging from $0.5 ; 1.5$; and 2 . all of which have different results.

Then we made a variation on the time of sonication, ie the time the sonic device worked to destroy papari cell walls so that the solvent could go inside and extract the papain enzyme better. Variation of time of used sonication is 10,20 and 30 minutes

Experimental results show that over time sonication will make the effectiveness in the extraction process to be better. It is characterized by an increase in protein concentration and enzyme activity in the sample. This applies to all variations in ratios where 30 minutes is the optimum time for running sonication, based on the experiments performed.

Meanwhile, the best ratio is 1.5 . this is because the mixture of ChCl-Oxalic Acid used reaches the optimum point of this $3 / 2$ mole ratio mixture. But when compared with ethanol as a conventional solvent, the yield of the NADES solvent is still far from expectations. ethanol still has much better extracts than NADES with $\mathrm{ChCl}-$ Oxalic Acid. It is characterized by higher protein concentrations and enzyme activity compared to any of the NADES mole variations.

The efficacy test is one of the testing stages to see how effective the pesticides are made. This test is done by applying pesticides (samples) that have been made to the broccoli leaf that became the food of one of the caterpillar pests. The hope after the pest to eat leaves given a sample of pesticides, will experience poisoning and eventually die

The efficacy test is performed by looking at the mortality rate or death of the pest after feeding on the sampled leaves. the results show that pests will die more quickly on sampled leaves that contain fewer extracted proteins, and slow to die on leaves in which there are many extracts. This means that the relationship between the mortality rate is inversely proportional to the result of the extracted sample being made.

\section{Conclusion}

From the graph above, it can be seen that the best time to do the sonication process is at 30 minutes and absorbance by using ethanol is the best absorbance. this is because that by using time 30 minutes means can make cell wall inside more can absorb the absorbance

\section{References}

1. Agustina. (2017). Kajian Karakteristik Tanaman Pepaya di Kota Madya Bandar Lampung. Lampung: Universitas Lampung.

2. Ali Fauzi, A. F. (2011). Pemanfaatan Buah Pepaya sebagai Bahan Baku Bioetanol dengan Proses Fermentasi dan Distilasi. Semarang: Universitas Diponegoro.
3. Baharudin, A., Suyanto, A., \& Sudaryanto, S. (2016). Pemanfataan Limbah Pepaya dan Tomat untuk Mempercepat Pengomposan Sampah Organik. Sanitasi, Jurnal Kesehatan Lingkungan Vol.8 No.2, 81-86.

4. Balai Penelitian Tanaman Buah. (2001). Laporan Hasil Penelitian. Solok: Balai Penelitian Tanaman Buah.

5. Bodo, E., \& Migliorati, V. (2011). Theoritical Description of Ionic Liquid. In S. T. Handy, Ionic Liquids - CLasses and Properties (pp. 123-142). Croatia: InTech.

6. Djojosumarto, P. (2008). Pestisida Dan Aplikasinya. Jakarta: Agromedia Pustaka.

7. Firda, D. (2017). Produksi Biopestisida Berbasis Enzim Sisteina Protease Dari Getah Pepaya Untuk Ulat Grayak pada Tanaman Cabai Merah. Depok: Universitas Indonesia.

8. Ghandi, K. (2014). A Review of Ionic Liquid, Their Limits and Applications. Green and Sustainable Chemistry, 44-53.

9. Grzonka, Z., Jankowska, E., Kasprzykowski, F., Kaspryzkowska, R., Lankiewicz, L., Wiczk, W., . . . Grubb, A. (2001, Januari). Structural Studies of Cysteine Proteases and Their Inhibitors. Acta Biochimica Polonica Vol. 48 No. 1, pp. 1-20. 